\title{
Budaya Konsumen dan Citra Perempuan dalam Media Massa
}

\author{
Suharko
}

\section{Pendahuluan}

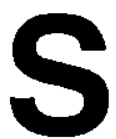

atu ciri penting yang kini menandai perubahan global, adalah gejala ekspansi pasar yang makin meluas dan intensif. Gejala seperti ini acap kali juga dikatakan sebagai globalisasi ekonomi. Suatu gejala global di mana belahan-belahan dunia menjadi satu kesatuan ekonomi, yang seolah mengaburkan batas wilayah negara-bangsa. Otoritas negara-bangsa yang dulunya kuat dalam mempengaruhi dan menentukan kebijakankebijakan ekonomi, kini nampak seolah lenyap oleh merebak dan menguatnya kekuatan pasar global.

Perubahan global ini ditandai oleh dua ciri penting (Evers, 1994). Pertama, pembentukan kesatuan-kesatuan ekonomi regional sebagai basis pemasaran produk ekonomi, seperti Pasaran Bersama Eropa (MEE), AFTA, NAFTA, dan APEC. Integrasi pasar melalui perdagangan ini, sebagaimana telah terjadi pada kasus MEE, diharapkan mampu mendongkrak penerimaan devisa negjara melalui aktifitas perdagangan. Kedua, munculnya pasar sebagai pusat orientasi kehidupan. Gejala ini tampak dari kecenderungan masyarakat dunia untuk menempatkan pasar sebagai acuan sentral dari perilaku konsumsi mereka. Pembelian produk tertentu tidak lagi ditentukan oleh dorongan kebutuhan terhadap fungsi atau nilai guna barang tertentu, akan tetapi lebih oleh dorongan-dorongan ekonomi yang diciptakan oleh pasar. Kecenderungan ini terutama sekali didukung oleh makin berkembangnya teknologi komunikasi-informasi melalui jaringan global media massa.

Kedua ciri perubahan global tersebut merupakan konsekuensi logis dari ekspansi pasar dunia. Negara-negara kapitalis lanjut (late capitalist states) mengandalkan perkembangan dan keberlanjutan ekonomi mereka melalui kekuatan pasar. Orientasi pokoknya adalah bagaimana memasarkan produk-produk industri dari seluruh potensi kekuatan ekonominya ke seluruh sudut dunia. Pembentukan pasaran-pasaran bersama sebenarnya hanyalah satu cara dari orientasi ekspansi pasar tersebut.

Lebih dari itu sebenarnya terdapat cara dan bentuk lain, yang memiliki kekuatan ekspansi yang jauh lebih besar, yakni pembentukan budaya konsumen (consumer culture) sebagai sendi utama pemasaran barang dan jasa. Logikanya adalah bahwa perilaku konsúmsi masyarakat akan sangat dipengaruhi oleh nilai-nilai sosial-kultural yang hidup dalam masyarakat. Dengan kata lain, produk-produk industri akan semakin dikonsumsi oleh masyarakat konsumen hanya jika konteks kulturalnya mendukung. Ini sungguh merupakan upaya strategi dan rekayasa budaya yang men- 
dasar bagi kelangsungan sistem ekonomi kapitalis, yang membutuhkan dukungan berbagai institusi, seperti institusi negara, ilmu pengetahuan, teknologi dan sebagainya. Tujuan akhirnya adalah bagaimana membujuk dan merayu masyarakat konsumen untuk membeli atau mengkonsumsi produk-produk industri. Ringkasnya, bagaimana merekayasa dan menciptakan secara terus-menerus kebutuhan-kebutuhan baru bagi masyarakat konsumen, yang sebenarnya dilihat dari nilai guna suatu produk tidaklah penting sehingga kebutuhan yang tidak penting menjadi kebutuhan yang penting.

Dalam konteks perubahan global yang ditandai oleh ekspansi pasar itu, tulisan ini ingin ditempatkan. Pengkajian akan difokuskan kepada beberapa pertanyaan berikut: apa yang dimaksud dengan budaya konsumen dan logika ekonomi apa yang mendasarinya? mengapa media massa, terutama iklan, merupakan agen penting dalam pembentukan budaya tersebut, dan yang terakhir dalam konteks meluasnya budaya konsumen, bagaimana perempuan dicitrakan dalam media massa?

\section{Budaya Konsumen}

Persoalan budaya konsumen sesungguhnya merupakan aspek penting dalam aktifitas ekonomi, akan tetapi kurang mendapat perhatian para ekonom. Para ekonom (terutama ekonom neo-klasik) hanya berkutat pada mekanisme penawaran dan permintaan. Perilaku konsumsi individu semata-mata ditentukan oleh hubungan selera (taste) atau preferensi yang stabil dan harga dan kuantitas barang dan jasa. Individu ditempatkan sebagai aktor yang memiliki perhitungan rasional-ekonomis. Konsumsi terhadap suatu produk diandaikan sebagai hasil dari mekanisme sarana-tujuan (means-ends). Jika seseorang merasa tertarik terhadap suatu barang (memiliki selera) dan harga barangnya terjangkau, maka orang tersebut pasti akan membeli barang tersebut. Karena itu, dalam pandangan ekonomi, individu adalah aktor yang rasional yang selalu memaksimalkan sumberdaya langka yang mereka miliki (Smelser \& Swedberg, 1994).

Tapi, benarkah proses sosial ekonomi akan sesederhana itu? Contoh sederhana barangkali cukup untuk membantah logika sarana-tujuan tersebut. Misalnya, mengapa seseorang membeli sebuah mobil mewah, yang sebenarnya dilihat dari nilai gunanya tidak perlu lagi bagi dirinya, karena ia telah memiliki sejumlah mobil? Logika yang menyatakan bahwa orang tersebut memiliki selera dan dengan kalkulasi rasional kemudian membelinya, agaknya tidak cukup logis. Sosiolog (baca: sosiologi ekonomi) akan memberi jawaban terhadap tindakan ekonomi (membeli mobil mewah) sebagai hasil dari bekerjanya budaya konsumen. Budaya konsumen adalah variabel sosial yang sangat penting dipertimbangkan dalam menjelaskan perilaku ekonomi dalam konteks masyarakat kapitalis lanjut.

Secara sederhana budaya konsumen adalah budaya yang secara dominan berorientasi pada pasar dan konsumsi barang dan jasa. Dalam budaya konsumen selera tidak hanya merefleksikan lokasi-lokasi sosial tertentu (seperti gender, okupasi, etnisitas dan sebagainya) tapi juga merefleksikan nilai sosial dan gaya hidup konsumen. 'Kedaulatan konsumen' (consumer sovereignty) yang dipermakhlumkan oleh para ekonom telah kehilangan signifikansinya dan tidak dapat menjelaskan proses ekonomi tersebut (Jary \& Jary, 199I).

Featherstone (sebagaimana dikutip Jary \& Jary, 1991:116) menyatakan bahwa dalam masyakat konsumen kapitalis maju, budaya konsumen dicirikan oleh tiga hal berikut: (a) konsumsi secara terus menerus 
didengungkan untuk produksi dan memberikan dorongan/bujukan kerjà; (b) konsumsi menjadi sumber diferensiasi status yang penting bagi semua kelompok sosial; dan (c) konsumsi menjadi sumber dari kenyamanan dan mimpi-mimpi. Ringkasnya, konsumsi adalah ide yang menjadi pusat dari segala orientasi masyarakat konsumen.

Tidak terlalu berlebihan jika dikatakan bahwa budaya konsumen dikendalikan sepenuhnya oleh hukum komoditas. Konsumen sebagai raja, yang memenuhi selengkap dan sebaik mungkin kebutuhan, aspirasi, keinginan dan nafsu-nafsunya. Budaya konsumen telah memberikan peluang setiap orang untuk asyik dengan diri sendiri (Piliang, 1995). Boudrillard menandai kondisi ini sebagai budaya 'permainan simbolsimbol' (play of symbols). Dalam bahasa lain Jameson menyatakan bahwa budaya konsumen merupakan sumber dari kerusakan keberlangsungan modemisme: melemahnya nilai-nilai inti modernitas, kaburnya distingsi kebudayaan tinggi dan kebudayaan rendah (high and low culture), dan mengaburkan beda antara standard dan rasionalitas (Kline, 1995).

Ciri atau watak dasar dari budaya konsumen itu sebenarnya bersumber dari ekspansi kekayaan yang luar biasa besar dalam masyarakat industrial. Dalam analisis Marx, kenyataan tersebut dipahami sebagai kelimpah-ruahan dan penekanan yang berlebihan pada komoditas dan produksinya di dalam sistem kapitalisme. Dalam sistem kapitalisme, 'nilai kerja' (labour value) akan menghilang dalam kalkulasi produksi komoditas: Karena target utama dalam produksi barang adalah 'nilai,-tukar' (exchange value) suatu komoditas. Dengan kata lain, nilai guna suatu komoditas diapropriasikan melalui produksi untuk pertukaran (Kline, 1995). Nilai guna yang semula mendasari produksi suatu komoditas kemudian kehilangan maknanya, dan yang muncul dan mendominasi pertukaran komoditas adalah nilai tukar. Seseorang memproduksi dan mengkonsumsi komoditas tidak lagi didasarkan pada nilai guna akan tetapi lebih pada nilai tukar.

Para ekonom, sebagaimana dinyatakan oleh Gaibraith, cenderung mengabaikan analisis tentang pengalaman konsumen dan mengecilkan arti dari teknik-teknik yang berkaitan dengan pembentukan relasirelasi sosial konsumsi melalui komunikasi seperti melalui iklan. Relasi-relasi sosial yang dibangun melalui komunikasi inilah yang perlu diperhatikan dalam memahami budaya konsumen. Relasi-relasi sosial tersebut berlangsung pada level tanda-tanda (significations) di dalam lingkup komunikasi yang meluas. Boudrillard menyebut gejala ini sebagai 'ekstasi komunikasi' (the ecstacy of communication). Menurutnya, ekstasi adalah perilaku yang menonjoi dalam budaya konsumen. la menyatakan:

dalam logika tanda-tanda, sebagaimana dalam logika simbol-simbol, objek tidak lagi terikat pada fungsi atau kebutuhan yang telah didefinisikan. Ini karena objek merespon sesuatu yang berbeda, baik karena logika sosial (social logic) maupun logika hasrat (desire logic), di mana objek-objek itu berjalan layaknya cairan dan suatu bidang tanda yang tidak sadar (sebagaimana dikutip Kline, 1995).

Dalam bahasa lain, relasi-relasi dalam budaya konsumen tidak lagi ditopang oleh nilai guna suatu komoditas, batas antara logika sosial (logika kebutuhan) dan logika hasrat (logika keinginan) menjadi kabur. Yang tampil adalah permainan simbolsimbol yang semuanya bermuara pada bujuk rayu untuk mengkonsumsi suatu komoditas. 


\section{Budaya Promosi dan Media Massa}

Dari paparan di atas jelas bahwa logika yang ada di balik budaya konsumen adalah logika bujuk rayu untuk mengkonsumsi komoditas. Dalam bujuk rayu itulah promosi merupakan aspek yang sangat penting bagi penjualan suatu komoditas. Hampir tidak ada satu komoditas pun dalam era pasar global sekarang ini dapat laku di pasar tanpa melalui promosi. Sejumlah perusahaan tidak jarang menghabiskan biaya produksi yang besar, karena alokasi untuk biaya promosi ini. Melalui berbagai media promosi ini sebenarnya kebutuhan-kebutuhan baru berupaya diciptakan dan dipompokan kepada konsumen oleh agen-agen promosi.

Salah satu agen terpenting dari budaya promosi (promotional culture) adalah media massa, terutama melalui advertensi atau iklan. Iklan berfungsi sebagai media yang mengantarai interaksi antara produsen dan konsumen. Melalui iklan, kelompokkelompok pemasar komoditas mengintepretasikan dan mensosialisasikan nilai guna dari suatu komoditas, dan memproyeksikannya ke dalam lingkup pasar global: Karena itu iklan merupakan bagian penting dari strategi pemasaran komoditas.

Strategi pemasaran di sini mengacu kepada kesempurnaan desain, teknik managemen dan komunikasi yang digunakan untuk mensintesakan dan mengkaitkan studi mengenai motivasi konsumen dan pengalaman 'nilai guna' suatu objek dengan taktik komunikasi yang persuasif melalui promosi untuk mempengaruhi konsumsi. Praktek-praktek promosi bisa jadi memang beragam, tapi setidaknya mencakup kesepakatan harga dan distribusi, hubungan publik, pengiklanan, program komersial, penempatan produk dan pemasaran silang. Dinamika komunikasi promosi ini telah memasuki dan membentuk semua domain kehidupan kultural yang secara gradual me- runtuhkan batas antara yang komersial dan yang kultural (Klein, 1995).

Dapat dipahami jika kemudian media massa (iklan) merupakan ujung tombak bagi promosi komoditas industri. Media massa di sini bisa mengacu kepada media cetak (surat kabar, majalah, dan media promosi cetak lainnya) maupun audiovisual (radio, TV, film dan sebagainya). Melalui media massa, proses komoditisasi segala sesuatu yang dapat mendukung budaya konsumen berlangsung. Dalam konteks masyarakat kapitalis lanjut, komoditisasi ini bisa mengena kepada hampir semua kelompok masyarakat, seperti anakanak, remaja atau pemuda, keluarga, perempuan, dan lain-lain. Melalui iklan, citra mengenai kelompok-kelompok masyarakat tersebut dibentuk, didiktekan, dan dikonstruksikan ke dalam bangunan kesadaran yang bermuara pada bujukan untuk mengkonsumsi suatu komoditas. Demikianlah maka, misalnya, anak-anak akan mengkonsumsi pakaian dan mainan yang bersimbolkan Power Ranger, karena citra anak yang baik adalah seperti yang tergambar dalam iklan dan film tersebut. Untuk konteks tulisan ini, pengkajian hanya akan dibatasi pada komoditisasi yang melanda kaum perempuan.

\section{Citra Perempuan dalam Media Massa: Komoditisasi}

Sebelum lebih lanjut melihat bagaimana citra perempuan dalam iklan di media massa, ada baiknya jika sifat dasar dan muatan makna yang terkandung dalam iklan diketengahkan terlebih dulu. Menurut Giaccardi (1995), iklan adalah acuan. Artinya, iklan adalah diskursus tentang realitas, yang menggambarkan, memproyeksikan dan menstimulasi suatu dunia mimpi yang hiper-realistik. Iklan tidak menghadirkan realitas sosial yang sesungguhnya. 
Apa yang nampak dan hadir dalam repertoar ikłan tidak lebih dari ilusi belaka atau rayuan terapetis yang tidak mencerminkan realitas yang sesungguhnya. Tanda-tanda (citra) iklan bukan merefleksikan realitas, meskipun bercerita tentang realitas. Iklan tidak bercerita bohong, tapi juga tidak bercerita sesuatu yang benar.

Dalam analisis historis Williams (During, 1993), iklan kini telah menjadi komponen yang vital dalam organisasi dan reproduksi kapital. Baginya iklan adalah 'magis' karena iklan mampu mentransformasikan komoditas ke dalam petanda yang glamor, dan petanda tersebut menghadirkan suatu dunia imaginer. Karena bersifat 'magis', iklan mampu menyihir konsumen untuk mengkonsumsi suatu komoditas.

Lalu bagaimana iklan bekerja? Menurut Frith (1993), iklan yang baik adalah iklan yang mampu berkomunikasi dengan kebudayaan. Dalam formulanya, iklan (advertising) adalah sama dengan komunikasi plus kebudayaan $(A=C+C)$. Menurutnya iklan bekerja dengan cara merefleksikan budaya tertentu ke konsumen. Produk tidak digambarkan sebagaimana adanya. Produk harus menjadi bagian dari sebuah cerita budaya. Upaya pengaitan citra produk dengan cerita budaya tersebut tidak lebih adalah sebuah rekayasa penggambaran kenyataan yang hiper-realistik (pseudorealistik). Atau, dalam bahasa Boudrillard, menampilkan yang lebih riil daripada yang riil (more real than real) (Elliot, Eccles \& Hodgson, 1993).

Dalam konteks citra perempuan dalam iklan, cerita budaya itu dibangun dengan memanipulasi tubuh wanita (outer body of women) sebagai tanda dari simbol-simbol tertentu yang secara stereotipis melekat pada diri wanita, seperti keanggunan, kelembutan, kelincahan, keibuan, kemanjaan, dan lain-lain. Iklan berupaya merepresentesikan kenyataan yang hidup dalam ma- syarakat melalui simbol-simbol tertentu, sehingga mampu menghidupkan impresi dalam benak konsumen bahwa citra produk yang ditampilkan adalah juga bagian dari kesadaran budayanya; 'meskipun yang terjadi bisa jadi hanya ilusi belaka. Menurut Yong-sang (1987), para ahli pembuat iklan seringkali secara sengaja menciptakan gambaran yang palsu (pseudo-reality) dalam iklan. Isi iklan berisikan manipulasi fotografi, pencahayaan dan taktik-taktik kombinasi lain yang memunculkan suatu pengalaman yang seolah-olah dialami sendiri (a vicorius experience).

Beberapa temuan penelitian berikut akan memperjelas kaitan antara realitas yang sesungguhnya dan realitas yang tersaji dalam iklan. Analisis isi terhadap media massa di USA selama 20 tahun terakhir menunjukkan media melebih-lebihkan dan mendistorsikan diferensiasi seks dalam distribusi demografi, karakter manusia, cara hidup, dan penghargaan sosial. Laki-laki digambarkan sebagai melebihi perempuan, memiliki otoritas dan status ekonomi yang lebih tinggi. Dalam karakter manusia, lakilaki digambarkan sebagai bernalar, efektif, independen, perintis, ambisius, positif, bijak, cerdas dan kuat; sementara perempuan dilukiskan sebagai emosional, tidak bernalar, bergantung, pasif, lemah dan penakut. Perempuan juga acapkali ditampi-kan sebagai objek seksual, dengan menekankan pada figur dan pakaian yang cantik, dan korban kekerasan. Media massa membatasi dan menekankan peran tradisional perempuan sebagai pengasuh anak dan penjaga rumah. Analisis isi terhadap program-program televisi untuk anak juga menunjukkan pola yang sama dalam diferensiasi seks.

Stereotip ini terjadi dimana-mana dalam media massa. Media massa di Korea secara terus menerus menghadirkan peran seksual yang stereotipis. Perempuan tetap 
saja dilukiskan sebagai ibu rumah tangga, pengasuh, dan bergantung pada pria Yongsang, 1987; lihat juga Venkatesan \& J. Losco, 1975; Sexton \& Haberman, 1974).

Di Indonesia media massa acapkali menampilkan perempuan sebagai objek seks. Perempuan teramat jarang ditampilkan sebagai wanita karier, pekerja, dan pemberi pendapat. Seorang pemimpin biro iklan menegaskan bahwa iklan selalu mengikuti citra masyarakat. "Kalau masyarakatnya stereotip, ya, iklan akan stereotip juga". Yang menarik adalah bahwa kaum perempuan lebih menyukai iklan yang menggambarkan peran yang tradisional

Penyajian iklan yang stereotipis agaknya juga berkaitan dengan segmen pasar yang dibidik oleh iklan itu sendiri, yakni kaum perempuan. Sebagian besar produk yang diiklankan oleh media Indonesia adalah produk untuk perempuan. Diandaikan bahwa perempuan adalah masih memegang peran penentu dalam konsumsi barang-barang dalam rumah tangga. Tidak heran jika perempuan adalah kelompok konsumen yang tengah digali (Tempo, 15 Pebruari 1992).

Di samping menyajikan citra yang stereo-tipis, iklan juga mempergunakan tubuh (the outer body of women) sebagai alat untuk menciptakan citra produk tertentu, atau setidaknya tubuh perempuan memiliki fungsi sebagai latar dekoratif suatu produk (Busby \& Leichty, 1993). Bagian-bagian tubuh perempuan acapkali dipresentasikan secara mencolok sebagai simbol yang sesuai dengan komoditas yang dipasarkan. Tubuh perempuan seringkali tampil sebagai simbol kenikmatan minuman, keindahan produk furnitur, keanggunan dan kelincahan produk mobil, dan sebagainya. Tubuh perempuan juga selalu menjadi alat dan simbol produk-produk dan desain pakaian, yang menampakkan sisi-sisi erotis dan keindahan produk tersebut .
Temuan studi Ferguson, Kreshel dan Tinkham pada tahun 1990, yang berupaya mengkaji pesan-pesan 'manifest' dan 'latent', menunjukkan bahwa selama 15 tahun terakhir di USA terjadi peningkatan yang dramatis citra perempuan sebagai objek seks dan sebagai aiat pemikat. Mereka menyimpulkan: "...bahkan dengan komitmen yang tegas terhadap citra perempuan yang non-stereotip, tingkat seksisme yang tinggi adalah bukti yang nyata dalam isi iklan" (sebagaimana dikutip oleh Busby \& Leichty, 1993).

Menurut Busby \& Leichty (1993), berbagai riset tentang citra wanita dalam media di Amerika, sejak tahun 1950 hingga 1980 menemukan bahwa ada gejala pengurangan citra iklan uang menampilkan wanita di rumah atau di dalam latar keluarga, dan peningkatan iklan yang menampilkan perempuan di tempat kerja. Akan tetapi, secara konsisten para peneliti menemukan peningkatan jumlah iklan yang menampilkan peran perempuan yang dekoratif atau memikat dalam iklan. Menurut mereka, para feminis memang telah berhasil mempengaruhi iklan sehingga terjadi perubahan citra perempuan dalam iklan yang lebih otonom selama empat dekade terakhir. Namun demikian, tidak semua arah dapat dipengaruhi, sehingga tetap saja iklan menampilkan citra perempuan yang subordinat, seperti penempatan peran perempuan sebagai objek dekoratif dan alat pemikat dalam iklan. Temuannya juga menunjukkan bahwa tidak ada kaitan yang berarti antara gerakan feminis di Amerika dengan perubahan citra perempuan dalam iklan. Hubungan yang nampak antara keduanya tetap saja bertentangan. Iklan dalam media massa tidak merefleksikan perubahan-perubahan yang terjadi dalam status sosial perempuan.

Temuan-temuan studi di atas menunjukkan iklan telah menyajikan citra perem- 
puan yang berlebihan dan tidak merepresentasikan realitas yang sesungguhnya. Citra stereotipis dalam iklan telah turut memperkokoh bahwa peran seks yang stereotip dan diskriminatif adalah sesuatu yang 'given'. Kenyataan bahwa pembagian peran seksual hanyalah konstruksi sosial belaka telah diabaikan oleh media.

Tubuh perempuan juga telah menjadi alat dan simbol dalam pemasaran suatu komoditas. Secara sepintas, barangkali citra perempuan yang menonjol tampak sebagai sesuatu yang tidak terelakkan dalam iklan, sehingga seolah-olah mencerminkan posisi sosial perempuan yang sesungguhnya dalam realitas. Padahal yang terjadi adalah sebuah proses sosial, melalui media, dimana tubuh perempuan diperlakukan sebagai tidak lebih dari komoditas yang dipasarkan itu sendiri. Dengan kata lain, yang terjadi adalah proses komoditisasi perempuan. Pengertian komoditisasi ini diturunkan dari konsep Marx tentang commodity fetishism, yakni perubahan menjadi sesuatu yang tidak alami objek-objek material yang dihasilkan oleh tenaga kerja manusia dalam kapitalisme ketika karakternya secara riil merupakan produk dari proses-proses sosial. Menurut Marx, proses perubahan seperti itu sebenarnya menyembunyikan fenomena terjadinya eksploitasi (Jary \& Jary; 1991: 4-5). Sebagai contoh, citra perempuan yang ditampilkan dalam iklan mobil seolah menunjukkan citra kekuatan dan keanggunan, padahal sangat boleh jadi di dalamnya terkandung nuansa eksploitasi tubuh perempuan.

Kesemua itu menegaskan bahwa media massa telah mendistorsikan nilai-nilai sosial. Dalam bahasa Simmel, apa yang semula tampak sebagai sesuatu yang etis telah berubah menjadi estetis. Presentasi tubuh perempuan dalam media yang semula sangat dibatasi oleh batasan-batasan etis, kini seolah terlepas dari nilai-nilai etis.
Apa yang ditonjolkan dalam iklan adalah lebih pada nilai estetika ketimbang nilai etika. Representasi realitas dalam iklan tidak lebih hanya kenyataan semu ( $p$ seudoreality) yang dipompakan dan dipaksakan sebagaj sesuatu yang riil terjadi dalam masyarakat.

\section{Catatan Penutup: Agenda Gerakan Feminis}

Dari paparan di atas terlihat bahwa konteks makro perkembangan kapitalisme lanjut (late capitalism) yang ditandai oleh ekspansi pasar (market expansion), jika dirunut secara lebih jeli, memiliki käitan yang signifikan terhadap ide tentang ketidaksamaan dan eksploitasi gender. Penyebaran dan sosialisasi budaya konsumen melalui iklan di media massa mengabaikan dan bahkan mengeluarkan ide tentang kesetaraan gender. Budaya konsúmen, sebaliknya malahan mereproduksi dan memperkokoh konstruksi ketidaksamaaǹ gender yang telah berlangsung. Ini tampak gamblang dari berbagai temuan studi tentang citra perempuan dalam media yang menunjukkan adanya citra yäng stereotip, perempuan sebagai objek seks, sebagai daya pemikat, dan citra-citra yang subordinat lainnya. Citra perempuan tidak lebih dari komoditas ekonomi, sebagaimana komoditas produk yang ditawarkan melalui iklan. Tubuh perempuan yang sebenarnya merupakan bagian paling pribàdi (privat) telah menjadi objek dan arena pembentukan citra produk, yang pada akhirnya bermuarakan pada bujuk rayu untuk mengkonsumsi suatu komoditas.

Komoditisasi perempuan melalui berbagai media promosi ini (terutama iklan) perlu mendapàt perhătian yang dekat dan serius; baik dari kalangan akademisi maupun para feminis di indonesia. Sosialisasi dan konstruksi sosial tentang gender yang 
stereotipis dan subordinat melalui media promosi memiliki jangkauan khalayak yang luas dan penetrasi yang intens, sehingga sangat strategis dalam pembentukan wacana gender masyarakat. Konferensi Wanita di Beijing (tahun 1995), dalam salah satu resolusinya, mengingatkan bahwa kecenderungan global ke arah konsumerisme telah menciptakan iklim di mana pesanpesan iklan dan komersial acapkali memotret perempuan sebagai konsumen dan target pemasaran berbagai komoditas. Daya pengaruh media promosi ini, yang hanya mengagungkan konsumtifisme, merupakan agenda gerakan feminis yang paling krusial ketika dihadapkan pada kenyataan makin berkembangnya pasar global yang kini tengah bergulir.

Para feminis perlu memikirkan bagaimana menyusun dan menyajikan suatu 'perlawanan budaya' (counter culture) untuk meminimalkan pengaruh dari penyebaran dan pembentukan budaya konsumen yang buta gender (gender blind) dan yang bersifat global. Agenda perlawanan budaya seperti itu setidaknya perlu dilakukan pada tingkat lokal, tentunya dengan basis kerangka pikir pada tingkat global. Dalam semboyan yang tengah populer di kalangan NGO: "think globally, act locally".

\section{Referensi}

Busby, Linda J. \& Greg Leichty, Feminism and Advertising in Traditional and Nontraditional Women Magazines 1950s-1980s", dalam Journalism Quarterly vol. 70 No. 2, Summer 1993.

Elliot, Richard., Susan Eccles \& Michelle Hodgson, "Recoding Gender Representations: Women, Cleaning Product, and Advertising's "New Man", dalam Intern. J. of Research in Mar- keting No.10, North-Holland, 1993.

Evers, Hans-Dieter, "Social and Cultural Dimensions of Market Expansion", paper presented at the Seminar, on Social and Cultural Dimensions of Market Expansion, Batam, Indonesia, 4-6 October 1994.

Frith, Katherine T., "Advertising in the Context of Eastern and Western Cultures: with Particular Emphasis on Indonesian Culture", dalam majalah Usahawan No.8 TH XXII, Agustus, 1993.

Giaccardi, Chiara., "Television Advertising and the Representation of Social Reality: A Comparative Study", dalam Theory, Culture \& Society, edited by Mike Featherstone, Vol. 12, Number 1, February 1995.

Jary, David., \& Julia Jary, Dictionary of Sociology, Harper Collins Publisher, 1991.

Kline, Stephen., "The Play of Market: On the Internationalization of Children's Culture, dalam Theory, Culture \& Society, edited by Mike Featherstone, Vol. 12, Number 2, May 1995.

Piliang, Yasraf A., "Ekonomi Libido dan Masyarakat Ekstasi", dalam majalah Prisma No. 9, LP3ES, Jakarta, 1995. Sexton, Donald E., \& Phyllis Haberman, "Women in Magazine Advertisments", dalam Journal of Advertising Research, vol. 14 No.4, Agustus 1974.

Smelser, Neil J. \& Richard Swedberg (Eds.), The Handbooks of Economic Sociology, Russel Sage Foundation \& Princeton University Press, New York, 1994.

Tempo, 15 Februari 1992

Venkatesan \& Jean Losco, "Women in Magazine Ads: 1959-71", dalam Journal of Advertising Research, vol. 15 No. 5, Agustus 1975. 
Budaya Konsumen dan Citra Perempuan dalam Media Massa, Suharko

William, Raymond., "Advertising: the Magic System", dalam Simon During (Eds.), The Cultural Studies Reader, Routledge, London, 1993.
Yong-sang, Park., "Women in the Mass Media", dalam Media Asia, vol. 14 No. 4, 1987.

ロロロ 